\title{
USOS E FUNÇÕES DAS IMAGENS SOB O PONTO DE VISTA DA IGREJA
}

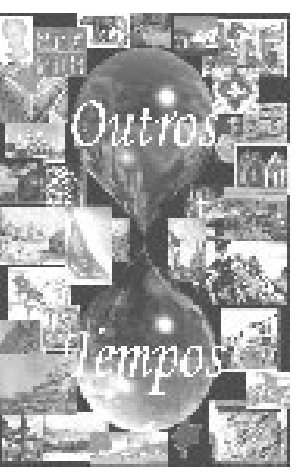

Talita Goulart Arrivabene

Mestranda em Artes - Universidade Federal do Espírito Santo

e-mail: talita_garrivabene@yahoo.com.br

Resumo:Este artigo faz parte da dissertação que desenvolvo atualmente junto ao Programa de Pós-Graduação em Artes da Universidade Federal do Espírito Santo. Nele, abordaremos o ponto de vista da Igreja Católica em relação aos usos e funções das imagens, partindo das legislações relativas ao assunto elaboradas em nível geral os concílios ecumênicos - e local - as decisões efetivadas de acordo com instâncias regionais, como bispados e paróquias. Trabalharemos em uma perspectiva de longa duração, buscando elucidar o início da problemática engendrada pelas imagens desde que estas começaram a ser utilizadas no mundo cristão, os caminhos tomados desde então e como a questão repercute na atualidade, em especial no Brasil e no Espírito Santo.

Palavras-chave:Imagens - Igreja - Concílios ecumênicos - Brasil - Espírito Santo

Abstract:This paper is part of the dissertation which I am currently developing for my Master's studies at the Postgraduation Program in Arts of the Federal University of Espirito Santo. In this text, we will discuss the point of view of the Catholic Church regarding the uses and purposes of images, based on the ecclesiastical legislations both on a general level - the ecumenical councils - and on a more local level - the decisions taken by regional instances, such as dioceses and parishes. We will work on a long term perspective, seeking to elucidate the beginning of the problem engendered by images since they began to be used in the christian world, showing the changes that have taken place, and how this issue still has reflections nowadays, specially on Brazil and on the state of Espirito Santo.

Key words:Images - Church - Ecumenical councils - Brazil - Espirito Santo

\section{Introdução}

A história das imagens é tão antiga quanto a história dos homens. Desde os tempos mais remotos, o homem se expressa por meio de representações (dos locais que habitava, dos animais, do próprio ser humano e, um pouco mais tarde, dos utensílios de que fazia uso).

Para a civilização cristã ocidental, a problemática da imagem assume um papel fundamental, afinal o próprio homem nada mais é que uma imagem: "E Deus criou o homem à sua imagem; à imagem de Deus ele o criou"(Gêneses,1,27). De fato, o homem é o ser feito como imagem de Deus, é sua expressão dinâmica, o ser relacional que é exteriorizado. Sem essa noção de imagem, não há percepção cristã ou definição de homem (PEREIRA, 2006). Desse modo, a imagem é o vínculo intrínseco e mais íntimo entre Deus e o homem: 
configura-se como a substância da qual ambos partilham, estabelecendo a comunicação entre divino e terreno, que se concretiza em detrimento da meditação e das orações que permanecem sempre no âmbito teórico-ideológico. Como mediação visível, a imagem é imbuída (consciente ou inconscientemente, cultural ou individualmente) de uma força capaz de atuar sobre as relações do homem com a sociedade e o meio em que vive. À medida que o tempo passa, transformam-se a aura, o prestígio e a irradiação das imagens. Entretanto, o seu poder atuante não perde o mistério. Estudam-se até hoje tanto as imagens produzidas por nossos ancestrais de Lascaux, como os ícones bizantinos e toda sorte de imagens, até chegar à própria arte contemporânea. Cada uma dessas formas de representação teve significados específicos, de acordo com a época em que foi produzida, mas todas continuam sendo, de alguma forma, importantes e também representativas para a atualidade.

Uma vez que nosso enfoque são as imagens cristãs, abordaremos, a princípio, sua problemática sob o ponto de vista de três concílios ecumênicos realizados pela Igreja, que representam as principais legislações eclesiásticas sobre imagens e que nos permitem analisar a questão em momentos significativos da história: o Concílio de Nicéia II (787), quando se intensificou o conflito entre iconoclastas e iconódulos; o Concílio de Trento (1562), na época da Reforma Protestante, e, mais recentemente, em um momento em que a Igreja passou por reformas e mudanças em muitos aspectos, o Concílio Vaticano II (1963). Trabalharemos numa perspectiva de longa duração, para melhor entendermos como se iniciou e se desenvolveu esse processo e suas repercussões nos dias de hoje.

\section{A legislação sobre imagens nos principais concílios ecumênicos}

A iconografia cristã apareceu no fim do séc. II, inicialmente nos sarcófagos e catacumbas, em muito suscitada pelos mitos bíblicos da imortalidade da alma. Essas representações, ainda bastante abstratas, demonstram o triunfo da fé sobre a morte, como aquele proporcionado pela ressurreição de Lázaro e de Cristo, algumas das imagens mais comuns no período paleocristão (BESANÇON, 1997, p.179). Entretanto, com a conversão do imperador Constantino no séc. IV e o surgimento das representações não mais simbólicas do próprio Jesus Cristo e de Deus, já que, pelo mistério da trindade, Deus é Pai, Filho e Espírito Santo (disse Jesus: “Crede-me: eu estou no Pai e o Pai está em mim”, João 14,11), reforçouse a discussão sobre a possibilidade, a autenticidade e as conseqüências de se representar o sagrado - não só os componentes da trindade santa, como também os santos, a Virgem Maria, 
os anjos, as próprias passagens bíblicas - uma vez que representar não é só evocar, mas tornar presente o ausente e, de certa forma, substituir (DEBRAY, 1993, p.38).

No cristianismo primitivo, sobretudo em Bizâncio, duas vertentes se contrapunham: os iconoclastas e os iconódulos. Os primeiros eram contrários às imagens, fundamentando-se sobre o argumento da proibição bíblica ("Não faça para você ídolos, nenhuma representação daquilo que existe no céu e na terra, ou nas águas que estão debaixo da terra. Não se prostre diante desses deuses, nem sirva a eles”, Êxodo, 20,4-5) e também na tradição judaica de não reconhecer em Cristo o Messias, desacreditando, portanto, no dogma da Encarnação, o que leva à impossibilidade de se representar o divino. Quanto aos iconódulos, estes se baseavam no argumento da Encarnação, através da qual o verbo se faz carne para se mostrar ao mundo, e na crença de que as imagens funcionam como uma forma de mediação entre o homem e a divindade, sem entretanto substituí-la (influenciados pela tradição grega de representar os deuses através de esculturas). Em princípio, a segunda opinião parece ter predominado: em 451, quando foi fixado o código da Encarnação no Concílio da Calcedônia, a Igreja passou a permitir oficialmente as imagens, desde que utilizadas na conversão dos pecadores e incrédulos e para fazer participar os fiéis na liturgia (DEBRAY, 1993, p. 83-88).

Entretanto, a decisão eclesiástica não foi aceita com unanimidade e a iconoclastia não deixou de existir. Pelo contrário, intensificou-se gradativamente. Exemplo desse fato é a atitude de Serenus, bispo de Marselha, que mandara destruir as imagens de sua sede episcopal. Em resposta, o papa Gregório Magno endereçou a ele uma carta, por volta do ano 600, em que destacava três funções principais das imagens: contribuir para o melhor entendimento das passagens bíblicas, especialmente para os iletrados que não têm acesso à palavra de Deus através da Bíblia Sagrada; trazer à memória a lembrança da vida dos santos mártires e de Cristo; além disso, suscitar a humildade e o arrependimento da alma que se descobre pecadora (BESANÇON, 1997, p. 243-244). É importante ressaltar que essa carta está na base de praticamente toda legislação cristã sobre imagens, tendo sido retomada em concílios e discussões posteriores que trataram dessa questão, notadamente no que se referia ao ensino da palavra bíblica através das imagens.

Mesmo com a crescente divergência entre iconoclastia e iconofilia, entre os séculos VI e VII ocorreu uma enorme difusão de imagens religiosas e do culto prestado a elas. A crise iconoclasta mais grave eclodiu em Bizâncio, em 725, quando o Imperador Leão III, o Isáurico, publicou os primeiros decretos iconoclastas, apoiado por alguns bispos. Em 730, 
ordenou a destruição de uma imagem venerada de Cristo, resultando em uma guerra civil que durou até 843 (BESANÇON, 1997, p. 188).

Nesse contexto ocorreu, em 787, o Concílio de Nicéia II, último concílio ecumênico em que o Ocidente e o Oriente participaram juntos, e que é um de nossos objetos de análise privilegiado. Houve uma grande preocupação, então, em esclarecer a questão das imagens, legitimando-as e, ao mesmo tempo, negando qualquer forma de idolatria:

quanto mais são contemplados (o Cristo, a Virgem e os santos) através de sua marca icônica, mais aqueles que os contemplam são levados a se lembrar de seus protótipos, a desejá-los e testemunhá-los, prestando-lhes uma veneração respeitosa, não uma verdadeira adoração, a qual convém somente à natureza divina (MARION, 1986, p. 459).

Os clérigos recorreram ao argumento da tradição bíblica da Encarnação ("No começo a Palavra já existia: a Palavra estava voltada para Deus, e a Palavra era Deus. E a Palavra se fez homem e habitou entre nós", João 1,1.14) para legitimar as imagens, não somente para afirmar a tese segundo a qual a pintura pode representar adequadamente os eventos evangélicos, mas também a de que há plena correspondência entre as imagens e a Escritura. Nisso observamos um reflexo do pensamento de São Gregório Magno quanto à importância das imagens em transmitir os acontecimentos bíblicos aos fiéis. Como São Gregório, o Concílio de Nicéia II destacou três funções das imagens: reavivar a memória dos fatos históricos, estimular a imitação dos personagens representados e permitir a veneração (MENOZZI, 1991, p. 25-26). Defendendo a possibilidade da imagem sacra, o Concílio de Nicéia II defendeu a humanidade do homem, sua origem sagrada e sua afinidade com Deus. A imagem sacra não foi tratada como resultado de uma teologia filosófica abstrata, mas como experiência viva da Igreja: sua fé, tradição, prática e espiritualidade (SAHAS, 1986, p. 447). A mensagem fundamental do concílio foi o otimismo de uma nova ordem das coisas que provém da Encarnação - afinal, o Verbo de Deus livrou o homem dos erros dos ídolos.

Houve, no entanto, um certo estranhamento do Ocidente em relação às decisões do Concílio. O rei carolíngio e os prelados da Igreja dos francos ocupavam uma posição moderada em relação às decisões conciliares. Rejeitavam absolutamente a possibilidade de uma transmissão (transitus) através das formas e das imagens, ou seja, não acreditavam que pudesse haver uma passagem entre a forma e o protótipo divino, pois estes tinham natureza totalmente diversa (no caso das relíquias e corpos dos santos, por exemplo, havia essa possibilidade de passagem, pois eram considerados matérias santas, de natureza divina). Enfim, a correspondência intrínseca declarada no Concílio de Nicéia II entre as imagens 
sacras e seus protótipos não foi aceita tão naturalmente, uma vez que, para os prelados da Igreja dos francos, a santidade provinha de duas razões: em relação aos seres racionais, das virtudes e, em relação aos objetos materiais, de uma consagração sacerdotal - nenhum dos dois casos se aplicava às imagens, que ficaram excluídas da hierarquia dos objetos sacros legítimos (SCHMITT, 1986, p. 273-275). De modo geral, vigorou a idéia de que as imagens não deviam ser destruídas nem veneradas, mas utilizadas para relembrar os fatos históricos e decorar as igrejas, como podemos constatar, por exemplo, nos Libri Carolini, escritos entre 790 e 792. Segundo estes, as imagens não poderiam dar acesso ao mundo espiritual, uma vez que a forma icônica forneceria somente aspectos materiais do que representam. A expressão verdadeira do espiritual deveria ser buscada em uma linguagem não-figurativa, sobretudo através das Escrituras ${ }^{1}$.

Apesar da permanente divergência de opiniões, seguiu-se um período de paz após o primeiro ciclo iconoclasta, encerrado teoricamente em 843 , quando o culto às imagens foi oficialmente estabelecido pela imperatriz Theodora em Bizâncio (SCHMITT, 1986, p. 280). Intensificou-se a produção de imagens no Ocidente cristão, mas as tendências iconoclastas persistiram no Oriente.

A questão jamais foi encerrada, eclodindo por vezes alguns movimentos contrários às imagens, como por exemplo as heresias. A iconoclastia reapareceu com força na Reforma Protestante. Martinho Lutero (1483-1546) e João Calvino (1509-1564) foram responsáveis pela difusão de idéias contrárias às imagens pela Europa. Calvino tinha uma posição mais radical, afirmava que "a arte nada pode ensinar a respeito do invisível. Só pode e deve mostrar as coisas que se vêem com os olhos" (CALVINO apud DEBRAY, 1993, p. 84). Muitas imagens foram destruídas seguindo esses princípios.

Além da questão das imagens, nesse período houve a preocupação de formar uma filologia sacra através de uma revivescência da Antigüidade. Alguns estudiosos se ocuparam de uma revisão sistemática do Novo Testamento grego, com a intenção de libertá-lo de traduções erradas e buscar o Jesus autêntico dos Evangelhos, certos de que uma das causas da superficialidade e da superstição vividas naquele momento era a ignorância em relação ao passado clássico. Mesmo Lutero apresentou essa preocupação, realizando uma tradução do Novo Testamento para o alemão, publicada em 1522 (PELIKAN, 2000, p. 172). Muitas traduções da Bíblia foram feitas, promovendo uma aproximação de Jesus e das figuras

\footnotetext{
${ }^{1}$ Ver MIRANDA
} 
bíblicas ao séc. XVI. A cultura renascentista não só apresentou uma teologia da encarnação vista como ponto fundamental da ortodoxia cristã - tendo Jesus como centro a partir do qual tudo se torna possível e para o qual tudo deve apontar, no qual tudo começa e termina - como também desenvolveu formas de representação adequadas à sua expressão. Se por um lado as imagens cristãs estavam sendo combatidas e destruídas, por outro passaram a ser entendidas de forma diferenciada e produzidas por artistas em cujas obras muitas vezes entrelaçavam-se sagrado e profano, em temas tanto mitológicos como bíblicos. Por exemplo, Botticelli representou, em 1486, o nascimento de Vênus e, em 1500, o nascimento de Cristo; Tintoretto pintou, em 1580, A origem da Via Láctea a partir do leite do seio de Juno e, entre 1592 e 1594, o sepultamento de Cristo (PELIKAN, 2000, p. 162-165).

O Concílio de Trento foi realizado nesse contexto, em 1562. Podemos observar em algumas de suas determinações referentes às imagens um claro reflexo das idéias de São Gregório Magno. Por exemplo, quando é enfatizada sua função pedagógica:

expressar e figurar histórias e narrações da sagrada Escritura é conveniente para instrução do povo ignorante: isto não é copiar a divindade, como se fosse possível vê-la com olhos corporais ou expressá-la com cores e figuras. Destitua-se toda superstição na invocação dos santos, na veneração das relíquias e no uso das imagens. (Disponível em: http://www.multimeios.org/docs/d000436. Acesso em: 27/08/06).

Observamos, nesta passagem, ainda outra questão, relacionada à superstição e ao paganismo, provavelmente em referência à religião popular e às heresias, havendo neste ponto concordância com os protestantes que acusavam atitudes supersticiosas e pagãs, por vezes no próprio catolicismo (na forma como as imagens eram reverenciadas, por exemplo). Ao aspecto pedagógico vem se juntar o de rememoração, que exorta os fiéis a seguirem os exemplos divinos:

as imagens não só recordam ao povo os benefícios e dons concedidos por Cristo, mas também expõem aos olhos dos fiéis saudáveis exemplos dos santos e dos milagres que Deus realiza com o fim de que a Ele dêem graças e regrem sua vida e costumes pelo exemplo dos mesmos santos e assim se voltem para adorar e amar a Deus, praticando a piedade. (Disponível em: http://www.multimeios.org/docs/d000436. Acesso em: 27/08/06).

Outras determinações tornaram a legitimar as representações de Cristo, de Maria e dos santos, como havia sido proposto no Concílio de Nicéia II:

devem-se conservar nos templos as imagens de Cristo, Maria e outros santos e dá-las correspondente prestígio e veneração. Não porque se creia que há nelas divindade ou virtude alguma pela qual mereçam culto, ou que se deva pedir algo, ou que vá se colocar a confiança nas imagens, como faziam outrora os gentios que colocavam sua esperança em ídolos, mas porque a honra que se dá às imagens se refere aos 
originais representados nelas. De sorte que adoremos a Cristo por meio das imagens que beijamos e em cuja presença nos descobrimos. (Disponível em: http://www.multimeios.org/docs/d000436. Acesso em: 27/08/06).

Chamamos atenção aqui para o caráter anagógico desse texto: o signo religioso remete ao protótipo, apresentando-se não somente como instrumento de pensamento, mas também como forma de estabelecer uma verdadeira comunicação entre o homem e a potência sagrada; busca construir uma ponte de ligação com o divino e, ao mesmo tempo, ressalta a distância e revela a incomensurabilidade entre ele e tudo o que o manifesta (VERNANT apud GINZBURG, 2001, p. 94). Vale ressaltar a diferença entre veneração e adoração, sendo esta somente adequada à natureza divina. A veneração é própria às imagens e ao que faz referência a tal natureza. Adorar as imagens seria considerado idolatria, mas venerá-las não. Existe aí um limite muito tênue que a Igreja se empenha em determinar bem, entretanto a contradição perdura, especialmente na vivência dos fiéis. Como adorar a Deus através das imagens sem cair na idolatria? Essa é uma das questões colocadas pelo Concílio Vaticano II, mais recentemente: manter o culto às imagens, mas com certo comedimento.

Outro ponto que merece destaque no período da Contra-Reforma é a ênfase no poder e na autoridade tão visados pela Igreja, na busca de afirmar um controle eclesiástico sobre a vida social da época. O Concílio de Trento determinou prévia aprovação e bênção das imagens pelo bispo, antes de serem expostas (MENOZZI, 1991, p. 41) e enfatizou o papel educativo dos padres, que deviam afastar os fiéis de toda forma de superstição e de doutrinas falsas ou imorais.

Vale ressaltar que essa normatização ficou mais a cargo da literatura - chegaram a ser desenvolvidos manuais de iconologia, como o de Cesare Ripa, no final do séc. XVI -, sem ter havido de fato uma sistematização oficial da Igreja.

O desenvolvimento da arte barroca entre os séculos XVII e XVIII ocorreu ainda no período da Contra-Reforma, em que a Igreja Católica recomendava mais austeridade na arte afinal, se esta devia seduzir a alma, que o fizesse em favor da fé (TOLEDO, 1983, p. 94). Numa época em que a Igreja perdia espaço para as novas vertentes protestantes, havia grande preocupação em proteger a fé católica e propagá-la. Nesse sentido, a imagem não encontrava em si mesma sua justificação, mas valia na medida em que era verossímil, comunicável e comunicada, demonstrando que até o que estivesse mais distante da experiência comum poderia, por meio da técnica, tornar-se perceptível e crível (ARGAN, 2004, p. 23 e 63). O que ocorreu, por um lado, foi um afastamento considerável da arte em relação às decisões do 
Concílio de Trento, à medida que os clérigos foram seduzidos pelo poder das imagens sagradas sobre o povo, especialmente os jesuítas, que se empenharam em difundir a doutrina nova após o Concílio, mas tiveram que se adaptar às resistências e exigências das massas que, com suas fortes aspirações pagãs, impuseram aos missionários respeito por certas tradições de suas culturas. Segundo Francastel,

\footnotetext{
não foi o espírito do Concílio que modelou a arte das gerações seguintes, mas a Igreja que se deixou arrastar, bem para além do que havia desejado, pelas tendências espontâneas do povo cristão e pela forma que uma tradição de fonte pagã estranha ao espírito sobrenatural e místico do catolicismo dava à devoção desse povo (FRANCASTEL,1973, p.421).
}

O que permaneceu de fato foi a permeação mútua entre sagrado e profano, cristão e pagão, nesse contato de culturas tão diferentes que, mesmo tentando se impor uma a outra, acabavam por criar novas culturas, onde alguns elementos permaneciam e outros iam sendo obliterados - às vezes pela força da destruição das imagens, ou simplesmente por não fazerem sentido, desaparecendo das representações. De qualquer modo, as representações continuavam permeadas por uma aura de mistério e transcendência, quer fossem essencialmente cristãs, pagãs ou um emaranhado de ambas. Cabe lembrar que, para algumas culturas pagãs, a imagem não era entendida como única forma de mediar a divindade, uma vez que os elementos da natureza já tinham essa conotação - o que, se por um lado ajudava o trabalho missionário (pois se a água, a terra, os animais... eram canal da divindade, as imagens também poderiam sê-lo), por outro lado complicava o entendimento desses povos (afinal, para eles as imagens eram tão divinizadas quanto os elementos animados e até inanimados de sua cultura) (GRUZINSKI, 2006).

Durante o Iluminismo do séc. XVIII, os argumentos científicos e filosóficos em que estavam balizados os milagres começaram a se romper, provocando mudanças em um cristianismo que havia, desde o princípio, se fundamentado principalmente sobre a origem divina de Jesus e a possibilidade de realizar tais milagres. Começou-se a entender a verdade divina como algo universal e não restrito somente à história de Israel e da Igreja. Jesus poderia ter influenciado até mesmo Sócrates, mesmo tendo-o sucedido historicamente. Esse tipo de paralelo era freqüentemente traçado em uma sociedade européia que acreditava ser a sabedoria humana o melhor meio de estabelecer a harmonia com a mensagem bíblica, uma vez que esta não se fundamentava mais na crença em um Deus ao mesmo tempo uno e trino (como Pai, Filho e Espírito Santo) nem nos milagres realizados por esse mesmo Deus, sobretudo através da segunda pessoa dessa Trindade. Em suma: não importava tanto que a 
origem divina de Cristo e seus milagres fossem comprovados, mas sim que se prestasse atenção à moral e aos preceitos que Ele pregava. Alguns defensores dessas idéias foram Benjamin Franklin (1706-1790) e Thomas Jefferson (1743-1826). Este, na busca de um "cristianismo purificado", chegou a editar os Evangelhos, deixando somente as partes que considerava autênticas. Nesse sentido, foram publicados A filosofia de Jesus de Nazaré e, por volta de 1820, A vida e a moral de Jesus de Nazaré extraídos textualmente dos Evangelhos em grego, latim, francês e inglês (PELIKAN, 2000, p. 204-205).

O séc. XIX, iniciado imerso nessa racionalização da religiosidade - o que é bem diferente da descristianização defendida por alguns autores - substituiu gradativamente o racionalismo pela visão romântica. Permaneceu a impossibilidade de considerar os milagres realizados por Jesus como verdades históricas literais, mas houve um empenho em integrá-los a uma visão mais abrangente do mundo. Pensadores como Ralph Waldo Emerson (1803-1882) e Friedrich Schleiermacher (1768-1834) buscaram ir além da antítese entre natureza e milagre ou experiência e fé, concentrando-se no significado das obras divinas traduzidas por uma consciência de Deus que se manifestava com força especial nos artistas e poetas (PELIKAN, 2000, p. 209-211). A experiência estética seria então a melhor forma de chegar a uma compreensão da mensagem de Jesus, não independente - mas certamente mais valorizada - de sua compreensão dogmática, moral e até histórica.

Se por um lado essas idéias tiveram como conseqüência um declínio do respeito e da valorização da Igreja, por outro a figura de Cristo continuou sendo reafirmada e reproduzida dos mais diversos modos e nas mais inusitadas situações. Ridicularizada e questionada por artistas contemporâneos como o argentino León Ferrari (1920- ), ela é colocada novamente no centro da questão. Não só Cristo, como os santos e Maria são re-convocados na obra deste artista, para citar somente um exemplo.

Assim chegamos ao séc. XX, no contexto do Concílio Vaticano II (1963), que pode ser entendido como uma forma de resposta às novas questões com que a Igreja se defronta. $\mathrm{O}$ capítulo intitulado "A conveniente promoção do progresso cultural" definiu que o homem pode investigar livremente a verdade, expor e divulgar sua opinião e dedicar-se a qualquer arte, desde que permaneça atento à ordem moral e ao bem comum.(Disponível em: http://www.vatican.va/archive/hist_councils/ii_vatican_council/index_po.htm. Acesso em: 21/04/2006). 
Por outro lado, Paulo VI reafirmou o valor permanente das decisões do Concílio de Trento, visando a um maior controle eclesiástico sobre a produção artística (MENOZZI, 1991, p. 60-61). Foi recomendado aos bispos que, em matéria de arte sacra, recusassem obras contrárias à fé, à moral e à piedade ou que ofendessem a sensibilidade religiosa autêntica e que se preocupassem mais com a beleza do que com a riqueza. Entretanto, a beleza das obras de arte sacra costuma estar intimamente ligada ao ouro, às pedras preciosas, à maestria de execução, enfim, à riqueza que ostentam. Exemplo disso é a Igreja de Nossa Senhora do Pilar, em Ouro Preto (Minas Gerais), cuja construção foi iniciada por volta de 1730, tendo sido usados em torno de $340 \mathrm{~kg}$ de ouro para dourar o interior. Dificilmente uma imagem feita em terracota no séc. XVI estará em alguma igreja importante; muito provavelmente estará num museu. O olhar do fiel é mais atraído quando as imagens são ricamente ornadas, quando suas vestes são suntuosas e seus olhos de vidro devolvem da forma mais real possível esse olhar. As representações das divindades devem prefigurar a majestade e a magnificência que se espera encontrar no Paraíso. Jesus, o mais humilde entre todos os homens, após sua crucificação e morte, sentou-se no "excelso trono do sublime reino", o mesmo que recebeu gloriosamente Maria, a mais humilde entre todas as mulheres, quando esta foi assunta aos céus (VARAZZE, 2003, p. 666). A humildade que se pede aos fiéis e que as próprias divindades demonstravam durante sua vida terrestre é substituída por todo o esplendor merecido e recebido ao se atingir a vida eterna. Quando as imagens não possuem tais riquezas, os próprios fiéis empenham-se em orná-las com boas vestes, cordões, brincos e anéis de ouro, como veremos em alguns exemplos na segunda parte deste artigo.

Quanto ao costume de expor imagens nas igrejas para veneração dos fiéis, a "Constituição conciliar Sacrosantum Concilium - sobre a sagrada liturgia" determinou que se devia mantê-lo, desde que fossem "em número comedido e na ordem devida, para não causar estranheza dos fiéis nem contemporizar com uma devoção menos ortodoxa”. (Disponível em: http://www.vatican.va/archive/hist_councils/ii_vatican_council/index_po.htm. Acesso em: 21/04/2006).

Observamos, nas decisões do Concílio Vaticano II, algumas dificuldades com que a Igreja se defronta desde então: primeiro, em coadunar o desenvolvimento da arte e das ciências à religião; em seguida, em desvincular a beleza e a eficácia das imagens sacras da riqueza que ostentam; finalmente, em adequar a realidade contemporânea com a reivindicação de maior liberdade artística à manutenção do controle sobre as obras que devem ou não ser 
expostas nas Igrejas. Chama-se atenção para o cuidado que se deve ter com as imagens expostas, mas o próprio Concílio não estabelece, de fato, uma legislação, não lista nem dá exemplos do que seria ou não permitido.

De fato, nenhum desses concílios forneceu regras estritas para a utilização ou para a confecção de imagens. Foram sempre amplos, fornecendo idéias gerais que eram posteriormente mais especificadas de forma objetiva e direta, como no caso dos manuais de iconologia, ou através de uma práxis.

\section{A questão das imagens sagradas no Brasil e no Espírito Santo}

A partir da Idade Moderna, há também resoluções tiradas em instâncias mais locais. No caso do Brasil, destacamos, para o período colonial, as Constituições Primeiras do Arcebispado da Bahia: publicadas em 1707, constituem a primeira legislação eclesiástica nacional, com intuito de regulamentar a situação das ordens e irmandades religiosas, além de abordar a questão das imagens, cujas referências tratam, sobretudo, de ocasiões em que devem ser tiradas do culto. Em primeiro lugar, as Constituições se preocuparam em esclarecer as diversas formas de veneração, a que ou a quem eram devidas e como proceder em cada uma delas: com a latria se adora a Deus, à Santíssima Trindade, a Cristo, à Eucaristia e às imagens do mesmo Cristo e qualquer outra cruz, como sinal representativo da verdadeira, em que o Senhor nos salvou, devendo-se prostrar de joelhos em terra, com a cabeça descoberta e as mãos juntas levantadas, batendo nos peitos e fazendo outros atos exteriores de veneração, que correspondam ao culto interior do coração; com a dulia devem-se venerar os anjos, espíritos celestiais e santos aprovados pela Igreja, rezando em pé ou de joelhos com a cabeça descoberta; a hyperdulia é própria à veneração da Virgem Maria e se faz descobrindo a cabeça e prestando-lhe oração com os joelhos em terra (VIDE, 1719).

A justificativa para o uso das imagens se baseou notada e declaradamente no Concílio de Trento, uma vez que as representações de Cristo, de Nossa Senhora e dos Anjos e Santos aprovadas pela Igreja deviam ser expostas nos templos e veneradas, não por serem portadoras de alguma divindade, mas pelas divindades a que se remetiam. Percebemos também um eco das idéias de São Gregório Magno quando as Constituições mandaram que se pusessem imagens nas igrejas, que se pintassem os retábulos ou se pusessem figuras dos mistérios realizados por Cristo, como forma de trazê-los à memória do povo, para que este se lembrasse dos benefícios e mercês que continuamente recebia e fosse incitado a dar graças a Deus e a 
Nossa Senhora e a imitá-los. Por outro lado, os bispos foram encarregados a ter particular diligência e cuidado com tais representações, não permitindo que houvesse "abusos, superstições, nem cousa profana ou inhonesta" (VIDE, 1719, TítuloXX: Das Santas Imagens, Parágrafo 696).

As Constituições revelaram grande preocupação com a decência das imagens, para que estivessem sempre de acordo com os mistérios e originais que representavam. Ordenaram que as imagens de vulto fossem feitas, daquele período em diante, "de corpos inteiros pintados, e ornados de modo que se escusem vestidos, por ser assim mais conveniente e decente" (VIDE, 1719, Título XX: Das Santas Imagens, Parágrafo 697). Nenhuma imagem deveria ser exposta sem antes ser vista e aprovada pelo Arcebispado e, quanto às imagens de vulto, deveriam ser previamente abençoadas na forma do Pontifical ou Ritual Romano. Foi determinado também que os visitadores examinassem as imagens atentos a qualquer forma de indecência, abuso ou erro contra a verdade dos mistérios divinos, até mesmo em sua vestimenta ou composição exterior. As imagens que se achassem mal e indecentemente pintadas ou envelhecidas deveriam ser retiradas de seus lugares de culto e enterradas nas igrejas, em local apartado das sepulturas dos defuntos. Já no caso dos retábulos impróprios, deveriam ser desfeitos em pedaços, queimados em lugar secreto, com as cinzas posteriormente lançadas na água da pia batismal ou enterradas, conforme dito anteriormente, sendo o mesmo observado com as cruzes de pau: (VIDE,1791, Título XXI: Que a imagem de Cristo se não pinte, nem levante em lugares indecentes, e que as Imagens envelhecidas se reformem).

Observamos que, mesmo impróprios, os elementos que serviam às imagens ou elas mesmas mantinham uma carga de significação e importância, não podendo somente ser descartados de qualquer forma. Um dos meios mencionados para dar-lhes fim é a queima, com posterior lançamento das cinzas na água da pia batismal, local onde se cumpre o primeiro sacramento, com uma água também sagrada. É como se as cinzas ali lançadas permanecessem de alguma forma santificadas - ou divinizadas - conforme a santidade que tinham (ou deveriam ter) ou a divindade a que remetiam (ou deveriam remeter). Já no caso do enterro, é frisada a importância de distanciar o local escolhido para enterrar imagens ou objetos que lhes servissem da sepultura dos defuntos: as imagens cristãs, por mais indevidas que se apresentassem, não eram indignas o suficiente para estar no mesmo local em que se deterioravam os corpos carregados de sua humanidade (e, após a morte, somente dela).

Quanto às imagens 
antigas que se costumam vestir, ordenamos seja de tal modo, que não se possa notar indecência nos rostos, vestidos ou toucados: o que com muito mais cuidado se guardará nas imagens da Virgem Nossa Senhora; porque assim como Deus não tem igual em Santidade, e honestidade, assim convém que sua Imagem sobre todas seja mais santamente vestida, e ornada. E não serão tiradas as imagens das Igrejas e levadas a casas particulares para nelas serem vestidas, nem o farão com vestidos, ou ornatos emprestados, que tornem a servir em usos profanos (VIDE, 1719).

Dava-se grande importância às vestes das imagens, que deveriam ser queimadas segundo o procedimento descrito anteriormente, caso não pudessem mais prestar ao culto. Além disso, era essencial que aquilo que servia para o culto servisse tão somente a ele, com a intenção de evitar uma contaminação do sagrado com o profano: as imagens não podiam nem mesmo deixar o local sagrado do templo - salvo as ocasiões em que eram feitas as procissões - e o que servia a elas devia ser-lhes próprio e individual. Mesmo as igrejas, imagens, vestes e demais objetos estando presentes e sendo fabricados em um mundo essencialmente corruptível e pecador, o templo sagrado e tudo que lhe servia devia representar o reino de Deus, aquele que, nas palavras de Jesus, não é deste mundo ( João,18,36), devendo estar afastado dele o máximo possível.

Houve preocupação também em estabelecer o lugar das imagens nos templos: no altarmor, precedia a todas em importância a imagem de Cristo, em seguida a da Virgem, depois a de São Pedro e só então a do orago da igreja. Este só teria primeiro e melhor lugar no caso de não haver as imagens anteriores (VIDE, 1719). Fora dos templos, as imagens nunca poderiam ser postas em lugares indecentes ou tratadas com menos reverência e acatamento do que lhes eram devidos. Não podiam, por exemplo, ser carregadas por pessoas que pediam esmolas (quer fossem pinturas ou imagens de vulto), sob pena de multa. Mais uma vez, observamos a tentativa da Igreja em manter a sacralidade e o respeito maior às imagens, mantendo-as nos templos e, no caso de estarem fora deles, que fosse em lugar mais decente possível (entretanto, novamente não são dados exemplos de que lugares ideais seriam estes, não é feita, de fato, uma legislação). Podemos imaginar que fossem lugares que servissem somente para o fim de expor as imagens, como oratórios domésticos, ornados dignamente, preferencialmente bentos e aprovados pela Igreja (RÖWER, 1936, p.175). Cabe frisar as imagens consideradas mais importantes naquela época, em relação ao lugar que ocupavam nas igrejas, e a modificação ocorrida sobretudo a partir do Concílio Vaticano II: permanecem igualmente importantes as representações da Virgem e do orago referente a cada igreja, mas a imagem de São Pedro dificilmente é encontrada atualmente e a de Cristo somente em alguns casos está presente no crucifixo. 
Nesta época, o Brasil ainda estava sob o regime do Padroado: eram os próprios reis de Portugal e, posteriormente, os imperadores do Brasil, os responsáveis por criar freguesias, nomear párocos e bispos, conceder benefícios e tomar decisões eclesiásticas (SCHIAVO, 1983, p. 32). A diocese do Espírito Santo estava eclesiasticamente sujeita à prelazia do Rio de Janeiro. Em 1880, quando da visita do bispo D. Pedro Maria de Lacerda à freguesia de Nossa Senhora da Penha, em Santa Cruz, chamamos atenção para sua atitude em relação às imagens que encontrou em determinada capela daquela localidade: o bispo deparou-se com

quatro oratórios com imagens de louça destas que os italianos vendem. Algumas por indecentes e quebradas eu as parti e mandei enterrar por respeito: e como algumas das antigas eram duras, foi preciso bater com um malhete, o que se outro fizesse poderia escandalizar (...). Havia ali uma imagem velha de São João Batista, estava vestida com uma túnica e tinha um menino Jesus nos braços! Tirei o menino Jesus e pus nos braços de uma imagem de Santo Antônio e despi o São João, deixando-o com sua túnica de pelos. A capella é de São Benedito e lá estava sua imagem, pequena e feia, mas toda coberta de cordões de ouro. (Livro de visita episcopal na província do Espírito Santo do Bispo D. Pedro Maria de Lacerda, $10^{\circ}$ Bispo do Rio de Janeiro, 14 de Julho de 1880 - 11 de Novembro de 1880).

Entendemos, a partir desta citação, que todas as imagens de louça ali encontradas eram indignas de estar expostas, quer fosse pelo material - louça, material barato que facilitava as reproduções sem exigir um trabalho maior como o do entalhe em madeira - quer fosse pela procedência - aquele tipo de imagem provavelmente era trazido em grande quantidade para ser vendido no Brasil (no caso, através dos italianos). Não obstante, o bispo visitador, não tendo respeitado com o devido rigor as diretrizes que as Constituições Primeiras do Arcebispado da Bahia prescreveriam para tal situação, estabeleceu uma distinção entre as imagens que mereciam ser dignamente enterradas e outras que, pelo contrário, foram violentamente quebradas (atitude que caberia somente ao próprio bispo, como ele mesmo frisa). Para os fiéis daquela freguesia, não importava tanto que as imagens fossem de materiais nobres ou artisticamente valiosas, nem que a iconografia dos santos fosse rigidamente respeitada (provavelmente, não era sequer conhecida: daí São João Batista estar com Jesus nos braços, ao invés de Santo Antônio). Isso se mantém de certa forma até a atualidade: muitas vezes a tradição popular entende determinadas invocações de forma errônea. Para aquela freguesia em Santa Cruz, o mais importante era ter representados seus santos de devoção e, no caso do orago, mantê-lo tão bem paramentado quanto possível: São Benedito, julgado por demais pequeno e feio por D. Pedro Maria de Lacerda, portava cordões de ouro obtidos muito possivelmente a partir do esforço da população local.

Com o início da República, o Governo Provisório, através do Decreto 119-A de 07 de Janeiro de 1890, proibiu a intervenção da autoridade civil nos assuntos eclesiásticos. A 
administração da Igreja foi entregue às arquidioceses, repartidas em bispados com paróquias canonicamente providas pela autoridade religiosa competente. No Espírito Santo, o bispado foi criado no dia 11 de Novembro de 1895, através do decreto Sanctissimo Domino Nostro, promulgado pelo Papa Leão XIII (CARNIELLI, 2005, p.276). Os bispos que exerceram o bispado em Vitória a partir de então também estabeleceram algumas diretrizes para a exposição das imagens nas igrejas locais, de acordo com o espaço deixado pelos Concílios para regulamentações internas.

O primeiro bispo do Espírito Santo, D. João Baptista Correa Nery (1897-1901), em sua visita realizada na diocese entre os anos de 1897 e 1900, deixou-nos vários exemplos de imagens que considerava impróprias e, portanto, deveriam ser tiradas de culto. É o caso da paróquia de São João Batista, de Carapina, com a imagem do Espírito Santo existente no altar-mor (Visita pastoral na diocese de D. João Baptista Correa Nery - 1897-1900,p.31). Já na paróquia de Nossa Senhora da Vitória, na capital, ele julgou as imagens regulares (Visita pastoral na diocese de D. João Baptista Correa Nery - 1897-1900,p.37), o que não ocorreu na maioria de suas visitas: na paróquia de São Pedro, em Cachoeiro de Itapemirim, tanto a imagem do Senhor Menino como outras imagens imperfeitas que compunham o altar de São Sebastião deveriam ser retiradas do culto e colocadas em um depósito, decentemente preparado para recebê-las. A imagem do orago, São Pedro, deveria ser trocada e a de Nossa Senhora das Dores, substituída. Na capela de São Gabriel, a imagem de São Sebastião não foi considerada própria para o culto público (Visita pastoral na diocese de D. João Baptista Correa Nery - 1897-1900,p.80-81;86). Em São Pedro de Alcântara de Itabapoana, o mesmo ocorreu com as imagens de Nossa Senhora da Penha, do Rosário e de Santa Cecília (Visita pastoral na diocese de D. João Baptista Correa Nery - 1897-1900,p.96).

Já na freguesia de São José do Calçado, o bispo deu ao vigário local a incumbência de julgar as imagens imperfeitas que deveriam ser afastadas dos fiéis (Visita pastoral na diocese de D. João Baptista Correa Nery - 1897-1900, p.103). Na freguesia de Nossa Senhora Mãe dos Homens, de São Pedro do Rio Pardo, várias imagens imperfeitas deveriam ser substituídas, entre elas: São Sebastião, Nossa Senhora da Penha e Nossa Senhora das Mercês, esta com o agravante de servir também para invocação de Nossa Senhora da Piedade, quando utilizada em sua face posterior (Visita pastoral na diocese de D. João Baptista Correa Nery 1897-1900,p.123), costume formalmente proibido pela Igreja ${ }^{2}$.

\footnotetext{
${ }^{2}$ Sobre essa questão, ver: PEREIRA, M. C. C. 2006 (no prelo).
} 
O bispo não deixou nenhum esclarecimento maior acerca destas imagens nem sequer justificativas para que fossem consideradas impróprias para estar em local de culto público. Talvez não fossem feitas com material suficientemente nobre ou estivessem quebradas, envelhecidas, com iconografias equivocadas (como no exemplo citado anteriormente de São João Batista e Santo Antônio), ou ainda, como no caso de Nossa Senhora das Mercês, poderiam ser usadas de forma inapropriada e não aceita pela Igreja. De qualquer maneira, observamos uma grande mudança na atitude deste bispo em relação ao anterior: ele não quebra as imagens nem as manda destruir, pelo contrário: em determinado caso é requisitada a preparação de um local decente para guardá-las. Sinal não só de maior consideração, como também de uma maior reflexão quanto ao que as imagens representavam (para a população que mantinha contato com as mesmas e para a própria Igreja).

Entre 1902 e 1916, o bispado foi exercido por D. Fernando de Souza Monteiro, que apresentou grande preocupação em regularizar as procissões freqüentes na capital durante aquele período. Por julgá-las em número exagerado - situação agravada pela falta geral de recursos que tornava ridículo o modo pelo qual se celebravam esses atos (em termos usados pelo próprio bispo) - ele as reduziu para três: a do Senhor Morto, na sexta-feira Santa, a de Corpus Christi e a do dia 8 de dezembro, na qual sairiam as imagens de Nossa Senhora Auxiliadora, da Conceição, de São Benedito, de São Sebastião e de outras invocações (Portarias circulares pastorais - documentos do governo eclesiástico, 1894-1918, p. 84v-85). Em contrapartida, intensificou as romarias ao Santuário da Penha (Livro de tombo Cúria Metropolitana,1950-1957, p. 16), destacando a importância de uma imagem que permaneceria por muitos anos como uma das de maior destaque do território capixaba. Até hoje ocorre a tradicional Romaria dos homens - geralmente em abril, levando a imagem de Nossa Senhora da Penha da Catedral Metropolitana de Vitória até o Convento de Nossa Senhora da Penha, em Vila Velha.

D. Fernando estabeleceu assim uma hierarquia de importância entre as imagens: havia aquelas dignas de exposição pública nas procissões e aquelas que, no máximo, poderiam acompanhar outra imagem mais importante processionalmente (como no exemplo do que ocorria anualmente em 8 de dezembro). Isso não foi aceito facilmente pelas irmandades e confrarias da época, que reivindicavam ter um dia específico para comemoração de seus santos de devoção. Elas parecem ter mantido seus festejos normalmente, pois estes continuam tendo inscrições praticamente anuais nos livros de organização interna da Igreja. 
O bispo que o sucedeu, D. Benedito Paulo Alves de Souza (1918-1933), era grande admirador das artes. Afirmava que Deus era o próprio Ser e a própria arte na sua plenitude e, sendo assim, as coisas produzidas pelo homem deviam transmitir a quem as visse e contemplasse a majestade divina (CARNIELLI, 2005, p. 320). Sua posição lembra um pouco a idéia que a Igreja procurava transmitir durante o período barroco: uma vez que a arte deveria convencer e atrair as pessoas, que o fizesse em favor da fé. As imagens deveriam ser, portanto, o mais belas e ricamente ornadas possível, afinal tinham a incumbência de transmitir a majestade de um Deus que era considerado, ele mesmo, a forma mais plena de a arte se apresentar. O retrato de D. Benedito, "símbolo do afeto e a expressão do acrisolado amor para com todas as suas ovelhas (Livro de Atas, 1913-1941,p. 34-35)”, foi inaugurado em sessão extraordinária no Consistório da igreja de São Gonçalo, com presença de representantes do Superior Tribunal de Justiça, oficiais do exército e do Corpo Militar de Polícia, representantes do clero e de diversas irmandades, confrarias, arquiconfrarias e demais associações religiosas. Não só as imagens sacras eram dignas de tratamento especial e solene, mas também o próprio retrato do bispo, recebido com louvor pelas maiores autoridades da época no templo mais importante de Vitória ${ }^{3}$.

D. Luiz Sortegagna (1933-1951) valorizava as devoções tradicionais da Igreja como meio eficaz para conservar e motivar a fé do povo. Exortou os fiéis às devoções de Nossa Senhora e dos santos, incentivando procissões, romarias, festas dos padroeiros (CARNIELLI, 2005, p. 337-338). No último ano de seu bispado foi comemorado o IV Centenário de fundação de Vitória, com festividades religiosas que incluíram a coroação Pontifícia da histórica e venerada imagem da Virgem da Penha que, pela segunda vez na história, foi recebida na capital. Descreveu-se da seguinte forma esse episódio:

Foi um delírio popular nunca visto... A mole humana se apinhava ao pé da Virgem da Penha. O retorno da sagrada imagem foi uma verdadeira apoteose. Em carruagem ricamente ornamentada sobre um trono de gloriosa rainha vai voltando para o Santuário. À tarde, a multidão, milhares de devotos se colocavam à margem nas ruas e estradas ovacionando entusiasticamente a veneranda imagem. Todos os veículos da cidade de Vitória e de Vila Velha se puseram em movimento, em direção da cidade do Espírito Santo. O percurso, da Catedral à saída da Capital, constituiu um evento nunca presenciado na cidade: a multidão se apinhava piedosa, rompendo de vez em vez em gritos de angustiosas súplicas a Virgem da Penha. Ao chegar em seu multisecular santuário, foi um delírio. Todos os habitantes de Vila Velha, bem como os peregrinos do interior assistiram a um espetáculo grandioso, quando se iluminou completamente o santuário juntamente com o Convento por meio de possantes refletores. Era ao cair da noite, o espetáculo foi simplesmente magnífico, arrancando de todos espontâneas palmas. Recolheu-se, assim, a Virgem ao

\footnotetext{
3 A Igreja de São Gonçalo estava funcionando como matriz, devido às reformas que se iniciaram em 1918 na catedral. Ver: Livro de provisões no 3 (1914-1922). Centro de Documentação da Mitra Arquidiocesana de Vitória - ES. p. $85 \mathrm{v}$.
} 
Santuário donde abençoava maternalmente os devotos deste e de outros Estados da Federação. (Livro de tombo Cúria Metropolitana, 1950-1957, p. 9)

Esta visita da imagem de Nossa Senhora da Penha constitui-se como exemplo do poder e da força que se atribuía às imagens naquela época (e que de certa forma permanece e pode ser observado em eventos posteriores). Fala-se freqüentemente em visita das imagens nos livros de inscrição interna da Igreja, como se a própria divindade viesse estar o mais perto possível de seu povo, estabelecendo um verdadeiro contato, muitas vezes realizando prodígios e até mesmo deixando saudades quando vai embora. O povo, em geral não satisfeito com a proximidade visual da imagem, sente necessidade de estar fisicamente o mais perto possível da mesma e de preferência tocá-la. No exemplo acima, apinhava-se em torno da representação da Virgem da Penha, buscando nela conforto para suas angústias e atenção para seus clamores.

Demonstração popular semelhante aconteceu durante o bispado de D. José Joaquim Gonçalves (1952-1957), quando da vinda da imagem de Nossa Senhora de Fátima ao Espírito Santo, em junho de 1953: recebida triunfalmente no Parque Moscoso, foi colocada num riquíssimo carro-andor, enfeitado com motivos da aparição, e acompanhada por enorme multidão até a praça da Catedral, onde foi coroada pelo bispo. Na despedida da imagem, o carro dos bombeiros a levou, "arrancando lágrimas de todos que a contemplavam. Seguia o carro oficial do governo, onde ia também o bispo e inúmeros carros, ônibus, caminhões... até o aeroporto, onde um avião da Força Aérea Brasileira aguardava para levar a imagem a Campos" (Livro de tombo Cúria Metropolitana, 1950-1957, p. 43-44.). Não só o povo, mas as maiores autoridades da época estiveram presentes para receber e acompanhar a imagem de Nossa Senhora de Fátima, tamanho o seu peso simbólico.

Em fevereiro de 1954, o bispo leu a circular da Santa Sé promulgada em 1939, em que o Soberano Pontífice exortava todos os sacerdotes a insistirem sempre de novo na necessidade de uma reforma de costumes e do revivescimento do sentido da verdadeira moral cristã (Livro de ata das reuniões do vigário da capital, 1954-1956, p. 1.). Talvez um prenúncio das mudanças que ocorreriam na década seguinte, com o Concílio Vaticano II. Entretanto, em agosto deste ano, durante a Semana Mariana, o fervor dos fiéis não foi menor quando a imagem do Imaculado Coração de Maria visitou todas as paróquias da diocese e o tradicional quadro de Nossa Senhora da Penha foi trazido para a Catedral, com posterior volta à Penha, num trajeto de mais de quatro horas feito a pé por diversos fiéis, que também ornamentaram suas residências com flores, luzes e imagens (Livro de tombo Cúria Metropolitana, 
1950-1957, p. 54). Na passagem do dia 21 ao dia 22 de agosto, o bispo insistiu para que todas as famílias expusessem uma imagem ou quadro iluminado de Nossa Senhora na janela de suas casas, deixando-o exposto pelo menos até depois da missa da meia-noite, convidando as famílias a rezar o terço em comum enquanto os homens estariam preparando-se para a comunhão da meia-noite. Em novembro deste mesmo ano, durante a novena da Imaculada Conceição de Maria, foi a vez da imagem de Nossa Senhora Aparecida visitar as várias paróquias de Vitória, levada ao Santuário da Penha na noite de 8 para 9 de dezembro (Livro de ata das reuniões do vigário da capital, 1954-1956, p. 13 e 16). Em 1957, quatro fac-símiles da imagem de Nossa Senhora da Penha, em peregrinação pela diocese, teriam realizado milagres e estimulado a fé dos fiéis (Livro de ata das reuniões do vigário da capital, 1954-1956, p. 62v). Percebemos ainda a forte influência da presença das imagens para os fiéis: não necessariamente a imagem original (no caso citado de Nossa Senhora da Penha), mas até mesmo cópias desta foram capazes de realizar milagres, em mais uma demonstração de que, para alguns fiéis, o valor artístico e histórico de determinada imagem não tem tanta importância quanto o que ela representa. O que importa é que a representação esteja o mais próximo possível, possibilitando a tão almejada mediação com a divindade.

No último bispado, exercido por D. João Batista da Motta e Albuquerque entre 1957 e 1958, temos mais demonstrações da importância da imagem de Nossa Senhora da Penha para o povo capixaba: fervorosas solenidades compuseram o ano dedicado a esta invocação da Virgem, estendido até o início de 1959 (quando se comemoraria o centenário das aparições de Nossa Senhora de Lourdes). O programa das festividades incluía procissão marítima com a imagem de Nossa Senhora da Penha acompanhada por vários iates, até o Convento em Vila Velha, e solenidades nos clubes náuticos de Vitória (Livro de atas do Rosário Perpétuo, 1954,. p. 24.).

Através da Constituição Apostólica Cum Territorium, o Papa Pio XII erigiu a província eclesiástica do Espírito Santo, criando a Arquidiocese Metropolitana de Vitória em 16 de fevereiro de 1958. Como arcebispo, permaneceu D. João Batista da Motta e Albuquerque até 1984. Foi o período do Concílio Vaticano II e houve grande preocupação, por parte de D. João, em renovar a liturgia de modo que os fiéis começassem a entender, participar e preparar com mais consciência as celebrações, e em conscientizar as pessoas sobre as decisões conciliares. Não só as celebrações como os costumes, ritos e devoções foram questionados, enquanto se buscava uma adaptação à nova visão da Igreja (CARNIELLI, 2005, p.522 e 537). 
Por um lado, o comedimento requisitado com relação às imagens tem provocado um crescente esvaziamento das igrejas. Por outro, esse comedimento anula-se em ocasiões como as procissões e as vindas de imagens importantes ao estado, como se os fiéis se sentissem novamente permeados pela presença da divindade que compunha tão freqüentemente as igrejas de outrora - em maior número e mais importantes artística e historicamente, as imagens compunham o ambiente aurático das igrejas em que o fiel, envolto por uma trama de olhares, via e se deixava ver.

De fato, em momentos de forte emoção, torna-se difícil estabelecer o devido e almejado limiar entre adoração e veneração, entre o que pode e deve ser feito diante de uma imagem e o que, aos olhos da Igreja, configura-se como excessivo e desmedido.

A quinta vez em que a imagem original de Nossa Senhora da Penha deixou seu santuário foi durante a visita do papa João Paulo II, quando D. Silvestre Luiz Scandian (1984-2004) era arcebispo do Espírito Santo. Carregada por aspirantes do $38^{\circ}$ Batalhão de Infantaria num veículo militar da corporação, a imagem chegou à praça onde foi incensada pelo papa, que se ajoelhou a seus pés na presença de inúmeros fiéis (CARNIELLI, 2005, p. 795). Mesmo após todo o comedimento proposto pelo Concílio Vaticano II, algumas imagens permanecem tão dignamente divinizadas que o próprio papa ajoelha-se diante delas, prestando a devida veneração prenunciada desde o Concílio de Nicéia II.

$\mathrm{Na}$ verdade, as imagens não deixaram de ter importância, nem ao menos tiveram esta diminuída. A repercussão das decisões conciliares constitui um processo ainda não terminado e permeado por interpretações por vezes errôneas. Segundo o cônego José Ayrola Barcelos, houve uma má interpretação do Concílio Vaticano II com relação às imagens,

não por maldade, mas devido à tendência muito forte que temos de adesão ao novo. Tudo que é novo nos empolga. A intenção do Concílio era chamar atenção para o principal da Igreja que era o altar, onde é celebrada a eucaristia, e também que o povo fosse levado a se voltar mais para capela do Santíssimo, para o sacrário, numa atitude de adoração. A orientação não é dificilmente assimilada, mas devido a essa tendência de se empolgar com o novo, muitos deram a interpretação de esvaziamento. (CARNIELLI, Antônio Adwalter. Entrevista realizada em 01 de maio de 2001 na Capela de São Camilo, Vitória - ES)

De modo geral, podemos notar um esvaziamento das igrejas em relação ao número de imagens, não só das igrejas mais recentes - que costumam ter um acervo iconográfico restrito a uma imagem de Nossa Senhora, outra de seu respectivo orago e uma cruz - como também de igrejas mais tradicionais, como a própria catedral metropolitana. Segundo o padre Carnielli, pároco da igreja de São Camilo na Mata da Praia, na metade do séc. XX, a catedral possuía um acervo composto por cerca de quarenta imagens, distribuídas em diversos altares 
laterais (CARNIELLI, Antônio Adwalter. Entrevista realizada em 01 de junho de 2001 na Capela de São Camilo. Vitória - ES. ). A grande maioria foi retirada após a reforma proposta pelo Concílio, ficando somente a imagem de Nossa Senhora da Vitória no altar-mor, duas imagens na lateral esquerda da entrada principal e a imagem de Nosso Senhor Morto, que não fica na nave da igreja. Essas mudanças provocaram grande insatisfação na população, pois mesmo sendo quase todas imagens de gesso, algumas haviam sido doadas por famílias e tinham grande importância para os fiéis: apesar de não ter grande valor histórico e artístico, representavam os santos de devoção com os quais o povo estava habituado.

Hoje, essas mudanças não são sentidas com tamanha intensidade. Os fiéis vêm, de certa forma, se habituando à diminuição de imagens nas igrejas, apesar de parte considerável manter seus santos de devoção, freqüentar procissões e ainda acreditar no poder de intermediação entre a imagem e a divindade.

\section{Considerações Finais}

Debray aponta algumas causas para diminuição da importância dada às imagens na atualidade. Em primeiro lugar, o afastamento da morte da vida social. Segundo ele, uma sociedade que não sente falta de nada, pois possui meios de guardar tudo, não precisaria mais de imagens, o que nos remete à segunda causa: a superprodução de imagens em que vivemos imersos (1993, p. 20 e 122). Em propagandas, nos filmes, em nossos álbuns de fotografias pessoais, encontramo-nos circundados por um mundo de imagens que nos atinge incessantemente e não nos fornece o tempo necessário para qualquer tipo de reflexão sobre o que vemos (se é que de fato vemos ou daríamos conta de ver). Por outro lado, entramos nas igrejas e elas estão vazias: seria ali então o espaço de reflexão por excelência, o momento de ter uma brecha na trama do visível que transborda fora de suas portas? Acreditamos que não. A igreja, enquanto lugar de encontro com a divindade - não só encontro espiritual, mas também material e concreto, através da Eucaristia como corpo presente de Cristo, conforme predizem as Escrituras - é onde, além de ver, o fiel se deixa ser visto, busca o olhar da divindade, em muito propiciado pela presença das imagens. Ao entrar nesses templos sagrados, passa-se do mundo onde impera o visível para o lugar do visual (DIDIHUBERMAN, 1994, p.164-165), ou seja, o lugar do mistério: não só da apresentação das imagens e das divindades ali representadas, mas de sua presentificação, onde as imagens não só atingem quem as olha, mas também se deixam ver e ser atingidas; onde as imagens não se 
colocam simplesmente diante dos olhos de quem as vê, mas exigem um trabalho desse olhar vinculado a um trabalho do próprio inconsciente do visível, daquilo que está por trás do que é visto.

Diante das imagens sacras, o homem é requisitado a sair da imersão do tempo em que vive e tornar-se novamente apto para a flexão temporal. Não viver somente o instante e supervalorizar o efêmero (DIDI-HUBERMAN, 1994, p.322) - como afirma Debray em sua terceira justificativa para a perda de poder das imagens- mas recuar interiormente, deixar que a história e a memória atuem diante do acontecimento único representado por cada imagem sacra.

No encerramento de seu livro, Pelikan diz que a mensagem e a pessoa de Jesus agora pertencem ao mundo (2000, p.248). De fato, como vimos, não só a pessoa de Jesus como também dos outros personagens bíblicos estão espalhadas pelo mundo através das mais diversas representações, recebendo dos tratamentos mais arbitrários e profanadores aos mais idolátricos e divinizadores. Entretanto, as próprias igrejas se constituem cada vez menos como lugar de encontro dessas representações. Quase completamente vazias de imagens, não propiciam a quem nelas entra a diferenciação entre visual e visível, a vivência do mistério em contraposição ao bombardeamento cotidiano de imagens. $\mathrm{O}$ olhar permanece vago e perdido, talvez apaziguado, uma vez que não mais atingido, mas também mudo, pois não encontra a possibilidade de diálogo.

Destacamos aqui a importância da igreja de São Gonçalo: seguindo o caminho inverso tomado pela maioria das igrejas a partir do Concílio Vaticano II, este templo se apresenta hoje com um acervo de quase trinta imagens, estando a metade delas disposta na nave e na capelamor. Uma trama de olhares constitui o lugar que abre novamente a possibilidade do visual e do diálogo entre imagem e espectador.

\section{REFERÊNCIAS}

ARGAN, G. C. Imagem e persuasão: ensaios sobre o barroco. São Paulo: Companhia das Letras, 2004.

BESANÇON, A. A imagem proibida: uma história intelectual da iconoclastia. Rio de Janeiro: Bertrand Brasil, 1997.

BÍBLIA. Português. Bíblia sagrada. Tradução da CNBB. São Paulo: Edições Loyola, 2002. CARNIELLI, A. A. História da Igreja Católica no estado do Espírito Santo: 1535-2000. Vitória: Comunicação Imprensa, 2005.

DEBRAY, R. Vida e morte da imagem: uma história do olhar no Ocidente. Rio de Janeiro: Vozes, 1993. 
DIDI-HUBERMAN, G. Poderes da figura: exegese e visualidade na arte cristã. In: Revista de Comunicação e Linguagens, n ${ }^{0}$ 20, Figuras. Lisboa, 1994, p. 164-165.

FRANCASTEL, P. A realidade figurativa: elementos estruturais de sociologia da arte. São Paulo: Perspectiva: EDUSP, 1973.

GINZBURG, C. Olhos de madeira: nove reflexões sobre a distância. São Paulo: Companhia das Letras, 2001.

GRUZINSKI, S. A guerra das imagens: de Cristóvão Colombo a Blade Runner (1492-2019). São Paulo: Companhia das Letras, 2006.

MARION, J.-L. Le prototype de l'image. In: BOESPFLUG, F. e LOSSKY, N. (ed.) Nicée II - 787 - 1987. Douze siècles d'images religieuses. Actes du colloque internacional. Paris, 2-4 oct., 1986. Paris: Cerf, 1986.

PELIKAN, J. A imagem de Jesus ao longo dos séculos. São Paulo: Cosac \& Naify, 2000.

PEREIRA, M. C. C. L. Identidades cambiantes: transformações iconográficas na imaginária sacra. Atas do IV Congresso Internacional do Barroco Ibero-americano. Ouro Preto, 2006 (no prelo).

PEREIRA, M. C. C. L. e FERREIRA, R. D. Um caso de homonímia sacra: o orago da igreja de São Gonçalo (Vitória - ES). Farol Revista de Artes, Arquitetura, Comunicação e Design - n.7.Vitória: UFES, Dezembro de 2006.

MENOZZI, D. Les images: l'église et les arts visuels. Paris: Les éditions du Cerf, 1991.

RÖWER, B. Diccionario liturgico. Rio de Janeiro: VOZES, 1936.

SAHAS, D. Icône et anthropologie chrétienne: la pensée de Nicée II. In: BOESPFLUG, F. e LOSSKY, N. (ed.) Nicée II - 787 - 1987. Douze siècles d'images religieuses. Actes du colloque internacional. Paris, 2-4 oct., 1986. Paris: Cerf, 1986.

SCHMITT, J.-C. L'Occident, Nicée II et les images du VIII au XIII siècle. In: BOESPFLUG, F. e LOSSKY, N. (ed.) Nicée II - 787 - 1987. Douze siècles d'images religieuses. Actes du colloque internacional. Paris, 2-4 oct., 1986. Paris: Cerf, 1986.

SCHIAVO, J. História eclesiástica do Espírito Santo. Revista do Instituto Histórico e Geográfico do Espírito Santo - no 34. Vitória - ES, 1983.

TOLEDO, B. L. de. Do séc. XVI ao início do séc. XIX: maneirismo, barroco e rococó. In: ZANINI, W. (org.) História geral da arte no Brasil. São Paulo: Instituto Walther Moreira Salles, 1983, 2v.

VARAZZE, J. de. Legenda áurea: vidas de santos. São Paulo: Companhia das Letras, 2003.

Artigos em meios eletrônicos

MIRANDA, Maria Adelaide. Hipertexto e medievalidade. Disponível em: www.educ.fc.ul.pt/hyper/resources/amiranda/hipertexto6A.htm. Acesso em: 16/05/2008.

PEREIRA, M. C. C. L. Uma arqueologia da história das imagens. In: GOLINO, William (org). A importância da teoria para a produção artística e cultural. Vitória, 2006. Site: http://www.tempodecritica.com/link020122.htm. Disponível em: http://www.vatican.va/archive/hist councils/ii vatican council/index po.htm. Acesso em: 21/04/2006.

VIDE, Sebastião Monteiro da. Constituiçoens primeyras do Arcebispado da Bahia. Lisboa: Officina de Paschoal da Sylva, 1719. Disponível em: http://docvirt.noip.com/demo/bma.htm. Acesso em: 17/08/07.

Documentação manuscrita

Livro de ata das reuniões do vigário da capital (1954-1956). Centro de Documentação da Mitra Arquidiocesana de Vitória - ES. 
Livro de atas (1913- 1941). Arquivo da Arquiconfraria de Nossa Senhora da Boa Morte e Assunção, Vitória - ES.

Livro de atas do Rosário Perpétuo (1954). Centro de Documentação da Mitra Arquidiocesana de Vitória - ES.

Livro de provisões no 3 (1914-1922). Centro de Documentação da Mitra Arquidiocesana de Vitória - ES.

Livro de tombo Cúria Metropolitana (1950-1957). Centro de Documentação da Mitra Arquidiocesana de Vitória - ES.

Livro de visita episcopal na província do Espírito Santo do Bispo D. Pedro Maria de Lacerda (10 ${ }^{\circ}$ Bispo do Rio de Janeiro) 14 de julho de 1880 - 11 de novembro de 1880. Centro de Documentação da Mitra Arquidiocesana de Vitória - ES.

Portarias circulares pastorais - documentos do governo eclesiástico (1894-1918). Centro de Documentação da Mitra Arquidiocesana de Vitória - ES.

Visita pastoral na diocese de D. João Baptista Correa Nery - 1897-1900. Centro de Documentação da Mitra Arquidiocesana de Vitória - ES.

Entrevistas

BARCELOS, José Ayrola. Entrevista realizada em 18 de maio de 2007 na Capela do Carmo. Vitória - ES. Entrevistadora: Talita Goulart Arrivabene.

CARNIELLI, Antônio Adwalter. Entrevista realizada em 01 de junho de 2001 na Capela de São Camilo. Vitória - ES. Entrevistadora: Talita Goulart Arrivabene. 